\title{
INTERNATIONAL ENTREPRENEURSHIP AS DEVELOPMENT OF ENTREPRENEURSHIP EDUCATION: A STUDY CASE OF ASEAN ECONOMIC COMMUNITY COUNTRIES
}

\author{
Dotty Wimpertiwi \\ Binus Entrepreneurship Center, Management Departement, Bina Nusantara University \\ J1. Kebon Jeruk Raya No. 27, Kebon Jeruk, Jakarta 11530, Indonesia \\ pertiwidw.kuliahS3@gmail.com
}

\begin{abstract}
The objectives of this research were (1) adding up the enrichment in the entrepreneurship education in BINUS to change the mindset of the students to be able to compete and create the new workspace in the AEC, especially in three countries (Indonesia, Malaysia, and Singapore) using PEST analysis to understand more about how doing entrepreneurship global or international; (2) Giving the contribution to enrich the knowledge of the basic concept of AEC for entrepreneur students; (3) Providing the insight on the challenge and the opportunity especially in International Entrepreneur. The research methods were qualitative and descriptive analysis follow by literature study. Results show that by learning entrepreneurship of ASEAN will change the mindset of the students to be more competing when doing business. There are several opportunity and challenge in neighboring countries between the member of the AEC, for the university that has the start-up or SMEs for being global or international.
\end{abstract}

Keywords: entrepreneurship, international entrepreneurship, Asean Economic Society (AEC)

\section{INTRODUCTION}

Entrepreneurship is one of the important characteristics when facing tight competitive knowledge economy in the globalization process, changing demographic structures, and fast-changing technology for firms and countries (Schumpeter, 1934; Halaç \& Bulut, 2012). Subsequently, university students are the national resources for being entrepreneurs in the future, which every effort to increase entrepreneurial intentions are important to create entrepreneurship education (Halaç \& Bulut, 2012). Therefore Bina Nusantara University as a world-class university with the vision, "A world-class knowledge institution in continuous pursuit of innovation and enterprise", translates the missions with high-quality objectives commitment and service to the community in the education field. While Bina Nusantara's mission is providing a world-class teaching, learning, and research experience that fosters excellence in scholarship, innovation, and entrepreneurship.

Bina Nusantara University which is focusing on the entrepreneurship development with one of its objective 'two out of every three graduates becomes an entrepreneur' has the responsibility to provide education to the students until the graduated and also monitor the graduates six months after graduation to be the entrepreneur. As the researcher is part of Bina Nusantara University's effort to achieve the goal, the closest challenge is the ASEAN Economic Society (AEC). The AEC, however, would be directed onto an integration of economic region that would reduce the cost of the trade, having better business facilities, and improving the competencies of the Small Medium Enterprises (SME), which opportunity for SMEs and startups born global or international (Braunerhjelm \& Halldin, 2019; Rodríguez-Serrano \& Martín-Armario, 2017). 
This is truly a new chapter of the ASEAN economic. However, it is important to be realized that AEC would push the wider competition in all aspects; it pushes the government and the business society to develop the better competencies (Oviatt \& McDougall, 2005). The occuring problem is how far the citizens, especially university students understand the concept of AEC and the challenges that come with it, and how they would react. The government indeed has the more crucial role in educating the citizens about the AEC. For that reason, the person who is curious about doing entrepreneurship and international entrepreneurship, should know about Political, Economy, Social and Technology (PEST) analysis (Gupta, 2013). The PEST analysis is a useful tool for understanding market as strategic management, especially when doing international entrepreneurship (Gupta, 2013; Loué, 2018; Lu \& Beamish, 2001), since a research about international entrepreneurship is important (Jones, Coviello, \& Tang, 2011) student of entrepreneurship must have more knowledge about it.

Based on these facts, there are some conditions that could be identified: (1) How the entrepreneurship education of Bina Nusantara university could change the mindset of the students to create the workspaces (by being entrepreneurs) and participate in the competition of the AEC? (2) The students have the ability to create excellent products or services, but the created products or services are not the kinds of solutions for the existing problems of the society, so the created products or services could not be accepted by the market. (3) Lack of information and fluency of the citizens, including the students about the AEC that ended up with the lack of interest to compete in the AEC. The objectives of this research are: (1) Adding up the enrichment in the entrepreneurship education in Bina Nusantara to change the mindset of the students to be able to compete and create the new workspace in the AEC, especially in three countries (Indonesia, Malaysia, and Singapore) using PEST analysis to understand more about how doing entrepreneurship global or international (Gupta, 2013), (2) Giving the contribution to enrich the knowledge of the basic concept of AEC for entrepreneur students, (3) Providing the insight on the challenge and the opportunity especially in the international entrepreneur.

\section{METHODS}

This research uses the in-depth interview with expert respondents who are business practitioners who have knowledge about AEC and or who already have a business globally. Moreover, it also uses the literature review methods from books and articles. The informants are the alumni of Bina Nusantara University and the entrepreneurs (global scale) who know how AEC works. The interview would be stopped soon if there are enough data and the purpose of research gained. The data analysis technique for this research is the qualitative data analysis that based on Miles and Huberman (2014). Which according to Miles and Huberman (1984), the activities in the qualitative data analysis should be done interactively and simultaneous on each step of the research.

\section{RESULTS AND DISCUSSIONS}

The universities as the integral part of the social and economic aspects of human kinds have already the consciousness about the importance of entrepreneurship. Entrepreneurship has been the part of the curriculum for years (Halac \& Bulut, 2012). Raposo and do Paço (2011) have stated that in the future, the entrepreneurship education and training should be focused on how to change the individual attitude, not only in education. The changes in individual attitudes would have more significant impacts on the new business creation aspects and the problem-solving attitude in the business. Based on Morris, Cornwal, and Kuratko (2013), there are 13 competencies that Entrepreneurs should have. Those 13 are opportunity recognition, opportunity assessment, risk 
management, conveying a compelling vision, perseverance, creative problem-solving, resource leveraging, guerilla skills, value creation, maintain focus, resilience, self-efficacy, and building and using the network.

In this research, an entrepreneur should have PEST analysis skill (Gupta, 2013) to understand about external environment and to sustain it (Singh et al., 2018). According to ASEAN (2013), AEC would be the main objective of international economic regional ASEAN that would be applied. The character of MEA (Masyarakat Ekonomi ASEAN/ASEAN Economic Community) are: (1) based the single and productive market, (2) a very competitive region, (3) the economic and economical place are fairly developed, and (4) the integrated region to the global economy.

According to Dosch (2017), AEC is formed based on four pillars. The pillars are (1) single market and production base, (2) competitive economic region, (3) equitable economic development, and (4) integration into the global economy. As MEA has been started, each country of the ASEAN should put the border aside. AEC would combine the market to be the single market. Positive impacts from AEC are the production activities would be highly increased in term of quantity and quality, stimulate the economic aspect of the country, citizens revenue leveling, national economic stability, more foreign exchange for the country, national needs would be fulfilled, and develop the workplaces. Nevertheless, AEC has the negative impact too. Some local production sale would be disturbed, the foreigner could exploit the natural sources in the AEC countries, and extremely tight competition.

AEC countries have policy to participate in MEA that supports the foreign entrepreneurs in Indonesia. The steps that have been taken by the government are improving the economic competitiveness by launching the accelerating and enlarging the Indonesian economic development master plans, Aku Cinta Indonesia program as the nation branding, strengthening the SMEs to be more creative, infrastructure improvement in all of transportation aspects; all access and even the information technology and electrical facilities, human resources improvement by building and rehabilitation more education facilities, reformation of the government such as corruption eradication, simplify the customs procedures, self-certification system, harmonizing the product standard, and SMEs Globalization programs (The World Bank, 2016a).

AEC countries have policy to participate in MEA that supports the foreign entrepreneurs in Singapura. The government has already created the atmosphere that could be beneficial for the foreign investor, as it is clearly shown in the Doing Business 2014. Singapore gives the simpler ways for the start-up companies by giving the tax exemption. The first $\$ 100.000$ would be tax-free for three years, and then after the $\$ 100.000$, the progressive tax would be applied. Government-aided equity financing schemes give the changes to the government and other parties to have a join business; cast grants so the entrepreneurs could communicate and get the access to get the capital; business incubator schemes help the new entrepreneur, not only financially but also providing guidance; debt financing schemes to get the loans to government in some certain set of episodes; tax incentive schemes; the investor (foreign) would not have to enter a joint venture company, or handing offer the management to the local investor (The World Bank, 2016c).

AEC countries have the policy to participate in MEA that supports the foreign entrepreneurs in Malaysia. Political and legally speaking, the policy that is made by the Malaysian government to the foreign entrepreneur could be considered as unstable, because some of the policies that support the entrepreneurs are only useful to support some certain political benefits (The World Bank, 2016b).

Indonesian political situation is considered as 'not interesting' because of political and social stability and the security guarantee of the law enforcement that are considered unstable. Law uncertainly is because of the powerless acts, labor problems are usually ended up with the demonstration, local autonomy remains unclear, government policy tends to change. Not only those factors when it is stated that the fact, but the corruption level in Indonesia is also considered as low. In 
Singapura, it is well known that the political issue is nearly zero. The situation is quite stable. However, Singapore needs to use their policy whenever there is a fraud. Malaysia has the similar problem with Indonesia that the politic situation is more or less unstable.

There would be some different regulation of each country that is being set to improve the development of internal entrepreneurs, yet still open to the foreign entrepreneurs. There would be several terms that should be fulfilled by the foreigner before they do business in Indonesia. The terms are (1) posses the sufficient education level, (2) posses the competency certificate or relevant experiences at least 5 years, (3) posses the a statement letter that he/she should be able to transfer their skill to the local staff that should be proven by report of trainings, (4) have the NPWN for the foreigners that have been stayed for more than 6 months, (5) and posses insurance policy in Indonesia, a member of Jaminan Sosial National for foreigners for the foreigners that have stayed for more than 6 months.

In Singapura, however, there are no differences between the local entrepreneurs and the foreign entrepreneurs. The prime minister himself has said that Singapore is truly opened for the foreigners that want to do business in Singapore. Singapore online allows the Private Limited (Pte. Ltd). The foreign company should have at least one local shareholder and director. Local director is the person that holds permanent resident status and stays in Singapore. If the company could not have that kind of partners, it could use the professional service such as heavy consultants as local passive directors. Foreign entrepreneur in Malaysia would not have to worry since there are no records of discrimination issues between locals and foreigners. However, the government has the policy to support and protect the foreigner from the unfair treatment. One of the informants has said that:

" Singapore has centered its focus on growing large number of startups or young companies by opening many accelerators and working with banks to allow more funding into the entrepreneur ecosystem. Malaysia has done the same and Indonesia; however, the legal requirements of both countries remain as the main problem of opening new businesses, especially for foreign entrepreneurs. Not very seldom this gets in the way of capturing the growing middle class of Indonesian market, which is the largest in the region. Singapore has kept its business rank very well, and Jakarta is catching up on that very quickly, especially with its rising young entrepreneurs." (Informant, International Social Entrepreneur, 24 years old)

The maturity is one of concern to develop entrepreneurship education by Kuratko (2005). The entrepreneurs should win the 'battle' in the international area by knowing the economic condition in the country, for how readiness the students becomes an entrepreneur (Condon, 2014). The economic condition in Indonesia has most population among the ASEAN countries. The income per capita does not seem to be balanced with the population. Singapore is the center of the ASEAN Economic, though Indonesia starts to catch up with the increasing significantly. Indonesia under Joko Widodo has applied several structural reformations to develop the economy in the long term, though it seems to be a bit painful in the short time. Indonesia is the market economy where the state-owned companies and high profile business players that play important roles. SMEs in Indonesia contribute approximately 99\% of the total active companies in Indonesia. In term of supporting the real sector, during 2010, Indonesia has made to reach the improvement of infrastructure capacities such as roads, railways, onland transportation, IT, and electrical.

Singapore is the smallest country in South East Asia, though, in economic terms, it is the top five income per capita country in the world. Singapore is in the 18th place of the wealthiest countries in the world. Last year, it was the top best economic at South East Asia. Economic players in Singapore are the most competitive players in the world that are considered as the densest country in the world. It has the best infrastructure in ASEAN; the road in Singapore is considered excellently 
managed and rarely traffic jam, Changi airport is considered as one of the best airports in the world as it has reached 400 international awards.

The population of Malaysia is in the sixth of ASEAN. Malaysia is considered very good in the economic development. However, the political crisis has made the economic to be unstable. The composite of Kuala Lumpur reaches the highest level ever in January, suddenly drops after the election; after the incumbent fails to reach the majority of seats in the parliament. It offers the railway and road network that has been managed excellently, and the existence of international airports and ports, with the excellent communication network. The government also gives the special package for the Iskandar Special District. The informant has said that:

"Singapore has long stood as the tiger in the region and continent. Growing competition in the region, Indonesia and Malaysia come fast with their more flexible solutions for entrepreneurs to open their businesses in their countries." (Informant, International Social Entrepreneur, 24 years old)

Kuratko (2005) has proposed some of the current challenges that his believe confront with entrepreneurship education, one of them is the technology challenge to develop entrepreneurship education. Comparison at technology between that three countries that Indonesia to be a little behind than the other countries in technology. Several indicators show it all such as the lack of technology and science contribution in the industrial sector, bad policy synchronization, and lack of scientists. Meanwhile, Singapore is the transit line in South East Asia, though it is small country, but it is cons idered as the most sophisticated country in term of technology. However in Malaysia though it is considered low, the technology specially at internet speed is improving. The telecommunication line in Malaysia shows some excellent improvement. It is said by the informant.

"Technology-wise, no other country is more ideal to be the leader in terms of technology with its world-class skills, Singapore alone has invested tremendously in technology and implemented a lot of what will be seen in other ASEAN countries soon. Incremental improvements are on their way to these countries." (Informant, International Social Entrepreneur, 24 years old)

\section{CONCLUSIONS}

Every country has the different environment to do entrepreneurship includes politic, economy, social, and technology (PEST). Indonesia, Malaysia, and Singapore; the three countries in South East Asia, also have different policies in doing PEST especially in economic terms and entrepreneurship. The knowing about that will enrich information and knowledge in entrepreneurship education for university students, inclusively Bina Nusantara University students. It will change the mindset to be more competing when doing business. There are several opportunity and challenge in neighboring countries between the member of the ASEAN Economic Community, for the university who have the start-up or SMEs being global or international.

There should be another research on the topic for other AEC countries so the students and other readers would have complete information about the all of AEC's member countries before they decide to do business there. The students and other readers are suggested to be able to use the information about AEC and keep on updated to the latest news considering the development of the information are extremely volatile and dynamic. 


\section{REFERENCES}

ASEAN (The Association of South East Asian Nations). (2013). ASEAN economic community blueprint. Retrieved from http://asean.org/wp-content/uploads/archive/5187-10.pdf.

Braunerhjelm, P., \& Halldin, T. (2019). Born globals - presence, performance, and prospects. International Business Review, 28(1), 60-73. https://doi.org/10.1016/j.ibusrev.2018.07.004.

Condon, J. (2014). Are your students ready to be entrepreneurs? Techniques: Connecting Education \& Careers, 89(5), 8-15.

Dosch, J. (2017). The ASEAN economic community: Deep integration of just political window dressing? Trans: Trans-Regional and National Studies of South Asia, 5(1), 25-47.

Gupta, A. (2013). Environmental and PEST analysis: An approach to external business environment. International Journal of Modern Social Sciences, 1(2), 34-43.

Halac, S. D., \& Bulut, Ç. (2012). Entrepreneurial education at universities: A conceptual framework. Journal of Entrepreneurship and Development, 7(1), 11-22.

Jones, M. V., Coviello, N., \& Tang, Y. K. (2011). International entrepreneurship research (19892009): A domain ontology and thematic analysis. Journal of Business Venturing, 26(6), 632659. https://doi.org/10.1016/j.jbusvent.2011.04.001.

Kuratko, D. F. (2005). The emergence of entrepreneurship education: Development, trends, and challenges. Entrepreneurship Theory and Practice, 29(5), 577-598. https://doi.org/10.1111/j.1540-6520.2005.00099.x.

Loué, C. (2018). Firms and internationalization: an approach based on the skills and the profile of the entrepreneur. Journal of Small Business and Entrepreneurship, 30(5), 345-374. https://doi.org/10.1080/08276331.2018.1459013.

Lu, J. W., \& Beamish, P. W. (2001). The internationalization and performance of SMEs. Strategic Managemen Journal, 22(6-7), 565-586. https://doi.org/10.1002/smj.184.

Miles, M. B., \& Huberman, A. M. (1984). Drawing valid meaning from qualitative data: Toward a shared craft. Educational Researcher, 13(5), 20-30. https://doi.org/10.3102/0013189X013005020.

Miles, B. M., \& Huberman, A. M. (2014). Qualitative data analysis: An expanded sourcebook (3 ${ }^{\text {rd }}$ Eds.). California: Sage Publication.

Morris, M., Cornwal, J., \& Kuratko, D. F. (2013). Entrepreneurship programs and the modern university. Massachusetts: Edward Elgar Publising Limited.

Oviatt, B. M., \& McDougall, P. P. (2005). The internationalization of entrepreneurship. Journal of International Business Studies, 36(1), 2-8. http://dx.doi.org/10.1057/palgrave.jibs.8400119.

Raposo, M., \& do Paço, A. (2011). Entrepreneurship education: Relationship between education and entrepreneurial activity. Psicothema, 23(3), 453-457. 
Rodríguez-Serrano, M. Á., \& Martín-Armario, E. (2017). Born-global SMEs, performance, and dynamic absorptive capacity: Evidence from Spanish firms. Journal of Small Business Management. https://doi.org/10.1111/jsbm.12319.

Schumpeter, A. J. (1934). The theory of economic development, an inquiry into profits, capital, credit, interest, and the business cycle. Cambridge, Massachusetts: Harvard University Press.

Singh, M. K., Kumar, H., Gupta, M. P., \& Madaan, J. (2018). A glimpse of sustainable electronics manufacturing for India: A study using PEST-SWOT analysis. Singapore: Springer.

The World Bank. (2016a). World bank group country at a glance: Indonesia. Retrieved from http://www.worldbank.org/en/country/indonesia.

The World Bank. (2016b). World bank group country at a glance: Malaysia. Retrieved from http://www.worldbank.org/en/country/malaysia.

The World Bank. (2016c). World bank group country at a glance: Singapore. Retrieved from http://www.worldbank.org/en/country/singapore. 